\title{
A Tomato Triploid Hybrid Whose Double Genome Parent Is the Male
}

\author{
Varda Kagan-Zur and Yosef Mizrahi ${ }^{1}$ \\ The Institute for Agriculture and Applied Biology, Ben-Gurion University of the Negev, P.O. Box \\ 1025, Beer-Sheva 84110, Israel
}

\author{
Dan Zamir and Nir Navot \\ Faculty of Agriculture, The Hebrew University of Jerusalem, Rehovot, Israel
}

Additional index words. Lycopersicon esculentum, isozyme analysis, restriction fragment length polymorphism analysis

\begin{abstract}
A spontaneous tomato (Lycopersicon esculentum Mill.) triploid hybrid was analyzed by isozyme and restriction fragment length polymorphism profiles. The double chromosome complement donor was shown to be the male parent, contrary to the prevailing hypothesis.
\end{abstract}

Obtaining triploid plants from crosses between tetraploids and diploids does work for some crops such as watermelon (Citrulus lanatus Thunb.) (Kihara, 1951) and lettuce (Lactuca sativa L.) (Eenink, 1980). However, this result is prevented by a strong block in other crops, such as alfalfa, (Medicago sativa L.) (Veronesi et al., 1986), clover, (Trifolium pratense L.) (Parrot et al., 1985), potato, (Solanum tuberosum L.) (Hanneman and Peloquin, 1968), and tomato (Nilsson, 1950). This problem is due not to lack of fertilization or nonviability of the embryo, but rather to endosperm failure (Cooper and Brink, 1945) stemming from chromosome imbalance (Johnston et al., 1980). Thus, any cross that fails to produce the right ratio of 2 maternal : 1 paternal chromosome complement will result in unbalanced endosperm, and, ultimately, in abortive seeds.

Apparently, viable $2 \mathrm{n}$ ovules and pollen grains are produced in 2n plants like potato (den Nijs, 1977), maize (Zea mays L.) (Rhoads and Dempsy, 1966), alfalfa (Veronesi et al., 1986), and clover (Parrot et al., 1985). A theory of direct tetraploidization through $2 \mathrm{n}$ gametes has been published (Parrot et al., 1985). However, triploid formation through such $2 n$ gametes resembles the difficult cross between tetraploids and diploids in that it produces unbalanced endosperm (Veronesi et al., 1986). However, spontaneous triploids may be obtained for many plants such as cannot be obtained by $4 \mathrm{x} \times 2 \mathrm{x}$ crosses, including soybean [Glycine max (L.) Merr.] (Chen et al., 1985), apple (Malus pumila Mill.) (Singh and Wafai, 1984), tomato (Rick, 1945), and cabbage (Brassica oleracea L.) (Mackay and Low, 1975). The prevailing hypothesis is that spontaneous triploids probably arise through the female parent as the donor of the double chromosome complement (Einset, 1948; Chen and Palmer, 1985). This path has been shown by Chyi and Weeden (1984) for certain triploid apple (Malus domestica Borkh.) cultivars. A possible mechanism may be a fertilized endosperm cell overtaking a degenerated fertilized egg (Munyamma, 1977).

Our study resulted from research aimed at estimating the commercial potential of triploid tomato fruits. An organized search for spontaneous triploids in commercial greenhouses was undertaken in the Negev (southern) area of Israel. Several hybrid triploids were discovered, and one, arisen in a greenhouse of the 'FC121' tomato hybrid, was studied. With appropriate hor-

\footnotetext{
Received for publication 18 Dec. 1989. We thank the Israel Endowment Fund (PEF) and the Israel Ministry of Agriculture for partial financial support of this work. The cost of publishing this paper was defrayed in part by the payment of page charges. Under postal regulations, this paper therefore must be hereby marked advertisement solely to indicate this fact.

'Also from the Biology Dept.
}

monal treatment its fruits are juicy, seedless, good tasting, and $50 \%$ larger than those of their diploid hybrid counterpart (Kagan-Zur et al., 1991). Its commercial potential is currently being assessed.

Since the triploid was a hybrid of two distinct lines, it enabled us to attempt to identify the double genome donor parent. Here we present evidence that spontaneous triploidy can be effected through the male parent and may be a common occurrence in tomato.

\section{Materials and Methods}

A spontaneous triploid ' $\mathrm{FC} 121$ ' tomato hybrid spotted in a commercial greenhouse in the Negev area and the diploid 'FC121' were propagated through cuttings. Parent lines of the 'FC121' were grown from seeds provided by N. Kedar. Cuttings were placed in half-strength Hoagland's solution (Hoagland and Arnon, 1950) and root primordia formed about a week later.

Root tips of freshly rooted cuttings were fixed by placing them in a saturated water solution of $\alpha$ - bromo-naphthalene for $165 \mathrm{~min}$ and then into 1:3 ethanol acetate for 12 to $24 \mathrm{hr}$. The tips were then placed for $5 \mathrm{~min}$ in 1 ethanol : $1 \mathrm{HCl}$ (concentrated), followed by $10 \mathrm{~min}$ of soaking in Carnoy solution. Orcein at $1 \%$ in 1 glacial acetic-acid : 1 water (aceto-orcein) was used as a chromosome stain as modified from Darlington and La Cour (1962).

Isozyme study. Leaf disks $\left(1 \mathrm{~cm}^{2}\right)$ were macerated on ice in a mortar in $0.1 \mathrm{M}$ Tris $\cdot \mathrm{HCl}(\mathrm{pH} 7.5)$ buffer containing $1.5 \%$ reduced glutathion. This crude extract was used without further treatment. Samples were electrophoresed for $6 \mathrm{hr}$ at $4 \mathrm{C}$ in $12.5 \%$ starch gels containing $0.005 \mathrm{M}$ citric acid at $\mathrm{pH}$ 7.0.

The gels were stained for aconitase (EC 4.2.1.3) according to Tanksley (1984) with the following modifications: NADP 10 $\mathrm{mg}$, MTT (thiasolyl blue) $10 \mathrm{mg}$, PMS (phenasine methasulfate) $2 \mathrm{mg}$, isocitrate dehydrogenase 30 units, cis- aconitic acid 50 $\mathrm{mg}$, all per $50 \mathrm{ml}$ of $0.1 \mathrm{M}$ Tris. $\mathrm{HCl}$ buffer at $\mathrm{pH} 7.5$. Gels stained for aconitase activity were scanned for estimation of relative stain density using an LKB 2202 Ultrascan laser densitometer (LKB, Bromma, Sweden). Units are arbitrary.

Restriction fragment length polymorphism analysis. Total DNA was extracted from leaves of the triploid 'FC121', the diploid 'FC121', and their male and female parents. DNA isolation, restriction digests, agarose gel electrophoresis, Southern blots, hybridizations, and autoradiography were as described by Bernatzky and Tanksley (1986). Genomic DNA at $15 \mu \mathrm{g}$ was digested with Eco RV and hybridized to the radiolabled DNA clone TG101 (Young et al., 1988). 

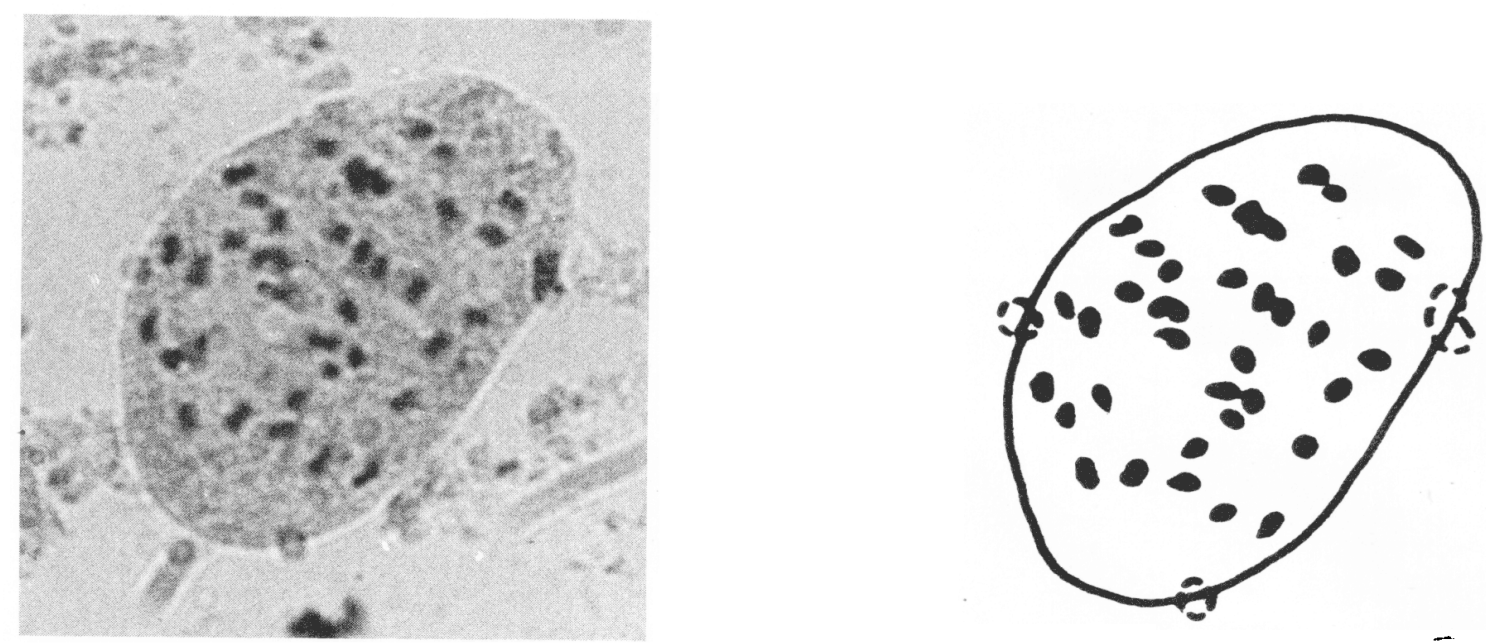

Fìg. 1. A representative triploid tomato root tip cell containing 36 chromosomes (magnification: $800 \times 4$ ). (Left) Photograph, (right) scheme.

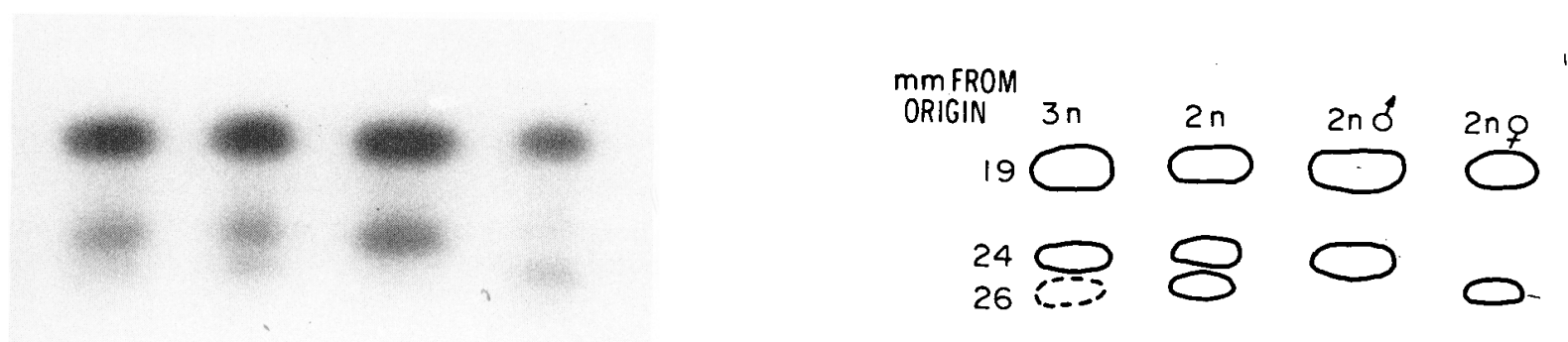

Fig. 2. Gel electrophoresis representation and photograph of aconitase isozymes of the triploid hybrid, the diploid hybrid, and parents of the (right) scheme.

\section{Results and Discussion}

Triploid tomato plants should have $2 \mathrm{n}=3 \mathrm{x}=36$ chromosomes. One triploid (Fig. 1) was verified among plants of the tomato hybrid line 'FC121'. This line, a hybrid of two distinctive parental cultivars, made a suitable subject for testing the prevailing hypothesis that a spontaneous triploid contains two maternal genome complements and one paternal genome (Chen and Palmer, 1985; Chyi and Weeden, 1984).

In some cases the number of gene copies of a particular isozyme can be established by examining the stain intensity of an electrophoresed sample (Tsaftaris et al., 1981). We tested (10) enzymes known to have more than one electrophoretic form. Only two differed between the two parents. In the esterase (EC 3.1.1.-) system the zymograms of both the $2 n$ and the $3 n$ samples were identical to the male parent, thus showing complete dominance and making esterase unsuitable for our purposes. In the aconitase system, only the monomeric ace-l was variable (Fig. 2). The female parent was homozygous for a fastmigrating allozyme and the male parent for a slower-migrating one. The diploid 'FC121' exhibited both allozymes at an intensity ratio of 3 male (slow-migrating) : 1 female (fast-migrating) (Table 1). This ratio probably reflects the differential expression of the two alleles in the heterozygote. The known phenomenon of allozyme imbalance in the heterozygote has been shown in maize to be due to different initial rates of
Table 1. Scan of an aconitase isozyme gel (using a Laser densitometer) from $3 n$ and $2 n$ tomato cv. FC121 hybrids and their parents.

\begin{tabular}{|c|c|c|c|c|}
\hline $\begin{array}{l}\text { Migration from } \\
\text { origin }(\mathrm{mm})\end{array}$ & $\begin{array}{c}\text { Triploid } \\
(3 n \\
\text { hybrid) }\end{array}$ & $\begin{array}{l}\text { Diploid } \\
(2 \mathrm{n} \\
\text { hybrid) }\end{array}$ & $\begin{array}{c}\text { Male } \\
\text { parent }\end{array}$ & $\begin{array}{l}\text { Female } \\
\text { parent }\end{array}$ \\
\hline $\begin{array}{l}19 \\
24(a) \\
26(b)\end{array}$ & $\begin{array}{r}1466 \\
425 \\
69\end{array}$ & $\begin{array}{r}1491 \\
289 \\
106\end{array}$ & $\begin{array}{r}1460 \\
397 \\
20\end{array}$ & $\begin{array}{r}1416 \\
0 \\
438\end{array}$ \\
\hline $\mathrm{a} / \mathrm{b}$ & $\approx 6 / 1$ & $\approx 3 / 1$ & -.- & $\ldots$ \\
\hline
\end{tabular}

translation (Freeling, 1983). The intensity ratio between male and female allozymes in the triploid was 6:1. If we assume that the relative expression of the alleles is the same as in the diploid hybrid, these results indicate that the triploid has two copies of the male allozyme and that it is the male parent that had contributed the double chromosome complement. Thus, our triploid plant may be the product of a haploid egg and a diploid pollen nucleus.

As the above result was somewhat surprising, a second, more conclusive approach was adopted. The male parent of the 'FC121' hybrid was homozygous for the $\mathrm{Tm}-2^{a}$ gene that confers resistance to the tobacco mosaic virus (TMV), while the female parent was susceptible to TMV. Young et al. (1988) demonstrated that the DNA clone TG101 was tightly linked to $T m-2^{a}$ and that restriction fragment length polymorphism exists be- 


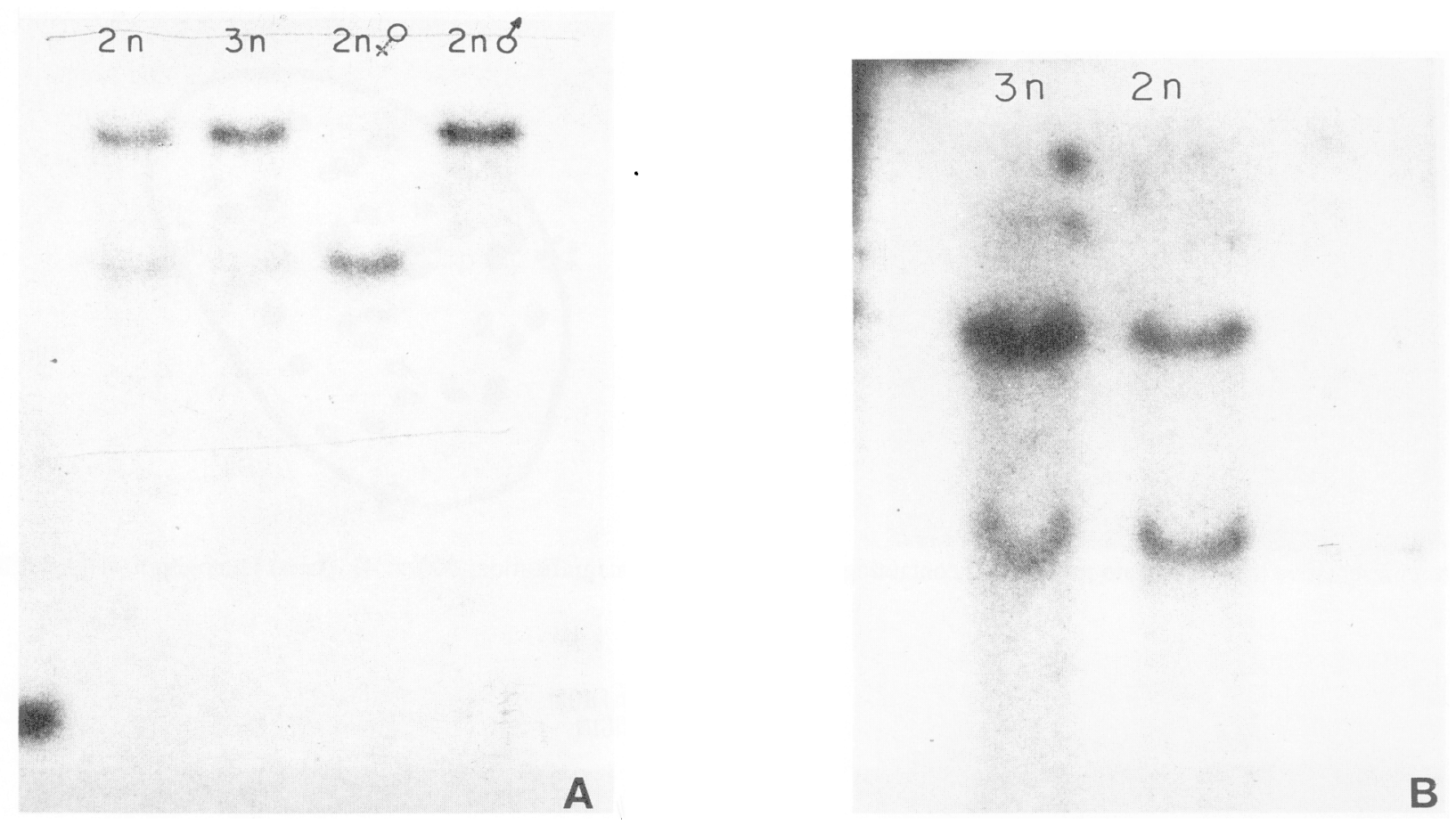

Fig. 3. An autoradiogram obtained from Southern blots containing genomic DNA from the male and female parents and from the diploid and triploid hybrids of the 'FC121' tomato cultivar. Genomic DNA at $15 \mu \mathrm{g}$ was digested with EcoRV and hybridized to the radiolabeled DNA clone $T G 101$.

tween TMV-resistant and -susceptible lines. TG101 was hybridized to a filter containing DNA of the two parents and the diploid and triploid hybrids digested with Eco RV. As expected (Young et al., 1988), the male parent proved to be homozygous to an Eco RV fragment of $8.5-\mathrm{kb}$ size, while the female parent was homozygous to a $4.5 \mathrm{~kb}$-size fragment. The diploid hybrid showed heterozygosity for the two allelic forms with similar intensities in the two bands. In the triploid hybrid, the hybridization signal of the $8.5-\mathrm{kb}$ band (male parent) was stronger than that of the 4.5-kb band (female parent) (Fig. 3). When the lanes of the diploid and triploid hybrids were compared, it became evident that the higher molecular weight band was more intense in the triploid hybrid (Fig. 3B), indicating again that the double complement donor parent was the male.

Dempsey (1961) reached a similar conclusion regarding the identity of the double complement donor parent through a statistical analysis of trisomic offspring of a cross between a triploid hybrid and carefully chosen diploid plants. Preliminary results for two more triploid hybrids currently under investigation in our laboratory point in the same direction. This combination may prove to be a general phenomenon in spontaneously arising triploid tomato plants.

The question arises how a viable seed could have resulted from such a cross [if the pollen grain is a true diploid, one should expect the endosperm not to develop properly (Cooper and Brink 1945; Johnston et al., 1980)]. Of all conceivable and rare schemes, the most likely to have occurred is either that both generative nuclei fertilized the egg while the vegetative (usually disintegrating) nucleus merged with the pre-endosperm nucleus to form a normally triploidic endosperm, or that when the haploid generative nucleus was about to fertilize the egg it underwent mitosis before merging of the two.

\section{Literature Cited}

Bernatzky, R. and S.D. Tanksley. 1986. Methods for detection of single or low copy sequences in tomato on Southern blots. Plant Mol. Biol. Rpt. 4:37-41.

Chen, L.F. and R.G. Palmer. 1985. Cytological studies of triploids and their progeny from male-sterile (ms1) soybean. Theor. Applied Genet. 71:400-407.

Chen, L.F., H.E. Heer, and R.G. Palmer. 1985. The frequency of polyembrionic seedlings and polyploids from ms1 soybean. Theor. Applied Genet. 69:271-277.

Chyi, Y.S. and N.F. Weeden. 1984. Relative isozyme band intensities permit the identification of $2 \mathrm{n}$ gamete parent of triploid apple cultivars. HortScience 19:818-819.

Cooper, D.C. and R.A. Brink. 1945. Seed collapse following matings between diploid and tetraploid races of Lycopersicon pimpinellifolium. Genetics 30:371-401.

Darlington, C.D. and L.F. La Cour. 1962. The handling of chromosomes. George Allen and Unwin, London.

Dempsey, W.H. 1961. Origin of a spontaneous triploid. Tomato Genet. Coop. Rpt. 11:10.

den Nijs, T.P.N. 1977. 2n gametes in potato species: occurrence, genetic basis and function in sexual polyploidization. PhD Diss., Univ. of Wisconsin, Madison.

Eenink, A.H. 1980. Plant characteristics for distinction of diploid, triploid, and tetraploid lettuce. Scientia Hort. 12:109-115.

Einset, J. 1948. The occurrence of spontaneous triploids and tetraploids in apples. Proc. Amer. Soc. Hort. Sci. 59:291-302.

Freeling, M. 1983. Isozyme systems to study gene regulation during development: a lecture, p. 61-83. In: S.D. Tanksley and T.J. Orton (eds.). Isozymes in plant genetics and breeding. Elsevier, Amsterdam.

Hanneman, R.E. and S.J. Peloquin. 1968. Ploidy levels of progeny from diploid-tetraploid crosses in the potato. Amer. Potato J. 45:255261.

Hoagland, D.R. and D.I. Arnon. 1950. The water culture method for 
growing plants without soil. Circ. 347, Univ. Calif. Agr. Expt. Sta Berkely.

Johnston, S.A., T.P.N. den Nijs, S.J. Peloquin. and R.E. Hanneman. Jr. 1980. The significance of genic balance to endosperm development in interspecific crosses. Theor. Applied Genet. 57:5-9.

Kagan-Zur, V., D. Yaron-Miron, and Y. Mizrahi. 1991. A study of triploid tomato fruit attributes. J. Amer. Soc. Hort. Sci. 116:228231.

Kihara, H. 1951. Triploid watermelons. Proc. Amer. Soc. Hort. Sci. $50: 217-230$

Mackay, G.R. and R.J. Low. 1975. Spontaneous triploids in forage kale Brassica oleracea. Euphytica 24:525-529.

Munyamma, M.V. 1977. Triploid embryos from endosperrn in vivo. Ann. Bot. 41:1077-1079.

Nilsson, E. 1950. Some experiments with tetraploid tomatoes. Hereditas 36:181-204.

Parrot, W.A., R.R. Smith, and M.M. Smith. 1985. Bilateral sexual tetraploidization in red clover. Can. J. Genet. Cytol. 27:64-68.
Rhoads, M.W. and Y.E. Dempsey. 1966. Induction of chromosome doubling at meiosis by the elongate gene in maize. Genetics 54:505522.

Rick, C.M. 1945. Field identification of genetically male sterile tomato plants for use in producing F1 hybrid seed. Proc. Amer. Soc. Hort. Sci. 46:277-283.

Singh, R. and B.A. Wafai. 1984. Intra cultivar polyploidy in the apple Malus pumila cultivar Hazratbali. Euphytica 33:209-214.

Tanksley, S.D, 1984. Aconitase isozymes: new gene markers for tomato. Rpt. Tomato Genet. Coop. 34:16-17.

Tsaftaris, A.S., J.G. Scandalios, and D.E. McMillin. 1981. Gene dosage effects on catalase expression in maize. J. Hered. 72:11-14.

Veronesi, F., A. Mariani, and E.T. Bingham. 1986. Unreduced gamets in diploid Medicago and their importance in alfalfa breeding. Theor. Applied Genet. 72:37-41.

Young, N.D., D. Zamir, M.W. Ganal, and S.D. Tanksley. 1988. Use of isogenic lines and simultaneous probing to identify DNA markers tightly linked to the $T m-2^{a}$ gene in tomato. Genetics 120:579-585. 